\title{
Energy sustainable cities. From eco villages, eco districts towards zero carbon cities
}

\author{
Anna Zaręba ${ }^{1, *}$, Alicja Krzemińska ${ }^{1}$, and Janusz Łach ${ }^{1}$ \\ ${ }^{1}$ University of Wrocław, pl. Uniwersytecki 1, 50-137 Wrocław, Poland
}

\begin{abstract}
Minimizing energy consumption is the effect of sustainable design technics as among many others: designing buildings with solar access and natural ventilation, using climate responsive design materials and effective insulation. Contemporary examples of zero-carbon cities: Masdar City, United Arab Emirates and Dongtan, China, confirm technical feasibility of renewable energy by implementation of solar PV and wind technologies. The ecological city - medium or high density urban settlement separated by greenspace causes the smallest possible ecological footprint on the surrounding countryside through efficient use of land and its resources, recycling used materials and converting waste to energy. This paper investigates the concept of energy sustainable cities, examines, how urban settlements might affect building energy design in eco-villages, eco-districts (e.g. Vauban, Freiburg in Germany, Bo01 Malmo in Sweden), and discuss the strategies for achieving Zero Emission Cities principles in densely populated areas. It is focused on low energy architectural design solutions which could be incorporated into urban settlements to create ecological villages, districts and cities, designed with consideration of environmental impact, required minimal inputs of energy, water, food, waste and pollution.
\end{abstract}

\section{Introduction}

According to scientific research quoted in the U.S. National Science and Technology Council report [1], 60 to $70 \%$ of energy savings in buildings can be achieved through different improvements (such as: passive heating and cooling, heat pumps, water conservation and recycling) and in addition about 30 to $40 \%$ of energy can be produced by renewable sources [2]. To achieve the significant energy savings, a simple system of urban metabolism, expressed as a linear combination of inputs (materials, energy, food and water), converted into outputs (waste: solid, liquid and gases) has to be expended to incorporate recycling technics (three R-Reclaim, Reuse and Recycle) [2, 3]. According the European Commission by 2050 it is estimated $80 \%$ cut in the EU greenhouse emission (intermediate GHG cuts of $25 \%$ by $2020,40 \%$ by 2030 and $60 \%$ by 2040 [4].

\footnotetext{
*Corresponding author: anna.zareba@uwr.edu.pl
} 


\section{Objectives of the research}

The paper focuses on the special characteristics of low energy consumption residential areas, introduces energy sustainable technologies, incorporated in architecture and urban scales (eco-villages, eco-district. ZEC), expressing the feasibility of existing design technics. This paper investigates the concept of energy sustainable cities, examines, how urban settlements might affect building energy design in eco-villages, eco-districts (e.g. Vauban, Freiburg in Germany, Bo01 Malmo in Sweden), and discusses the strategies for achieving Zero Carbon Cities principles in densely populated areas. The aim of the studies was to determine the scale and extent of the energy-sustainable architecture phenomenon (ZEB) and highlight the diversity of projects, introduced in different climatic conditions. The research was based on identifying contemporary eco-village, eco-district and eco-city initiatives, through the analysis of the relevant literature, reports, government and policy documents, conference proceedings and websites of international networks relevant to energy-sustainable communities initiatives.

\section{ZEB - Zero Energy or Zero Emission Building}

The term "ZEB" is related to Zero Energy Building and Zero Emission Building. The Zero Energy Building refers to energy consumed by a single construction (residential or commercial building), the Zero Emission Building refers to the carbon emissions produced by a building, which is reduced to minimum [5]. ZEB types can be divided into Autonomous ZEB (energy self-sufficient free standing structure) and NetZEB (energy neutral building, delivering the same amount of energy it returns) connected to the community network [5,6]. According to Energy Performance of Building Directive [7] $\mathrm{ZEB}$ :"has a very high energy performance with a low amount of energy required covered to a very significant extent by energy from renewable sources, including energy from renewable sources produced on-site or nearby". In the ZEB or nearly ZEB, according to European Commission: "we will live and work in low-energy, low-emission buildings with intelligent heating and cooling systems. We will drive electric and hybrid cars and live in cleaner cities with less air pollution and better public transport" [4]. According to the European Union Directive on the energy performance of buildings (Directive 2010/31/EU) all new building ought to be designed as nearly zero-energy houses from 2020 and the European Strategic Energy Technology Plan (SET-Plan) assumed, that at least half of the existing buildings in 25 demonstration cities should be transformed into nearly zero energy buildings by 2020 [8]. A nearly zero-energy building is defined in Article 2 of the EU Directive as "a building that has a very high energy performance. The nearly zero or very low amount of energy required should be covered to a very significant extent by energy from renewable sources, including energy from renewable sources produced on-site or nearby" [7].

Energy savings can be achieved through various practices: adaptation the design to local climate condition and topography, use of environmental building design technics, such as: passive solar systems, natural ventilation, proper thermal insulation of the buildings (solid and vaccum insulation, vaccum windows and cool roofs) [8]. Most of energy is produced on-site or off-site, on the basis on Renewable Energy Sources (REN), including: solar (solar photovoltaics, solar-thermal power systems incorporated into buildings), biomass-, wind-, hydro- and geothermal energy systems. Nevertheless off-site technologies, exploiting the wind, hydro or geothermal energy cannot be easily introduced in densely populated area. 
Heating, Ventilation and Air-Conditioning (HVAC) systems (heating, hot water, airconditioning and ventilation systems) are supported by intelligent, computer based, Building energy Management Systems (BMS) [8].

On the basis on the way a given building is supplied with energy, Lund at al. [9] distinguished four types of ZEB: APV-ZEB - building equipped with photo-voltaic system (PV), Wind-ZEB with on-site wind turbines, APV-Solar thermal-heat pump ZEB with combination of PV installation, APV-solar thermal collectors and a heat pump and heat storage system, and A wind-solar thermal-heat pump ZEB.

\section{Eco-Village}

The term eco-village was coined by Robert Gilman (1991) in the paper "The Ecovillage Challenge" and defined as: a combination of a human habitat and human activities which does not cause environmental damage and support human health [10]. Average eco-villages range from a population of 50 to 150 inhabitants. Ecovillages combine social, ecological and economic aspects. Eco-villages cause minimal ecological impact using alternative systems of: energy, water, transportation and waste-treatment. Dawnson [11] highlights five features, which describe eco-villages principles: non-governmental projects, strong communities, provision and distribution of the natural sources of water, energy and food and strong sense of shared values. In the context of energy distribution the basic assumption is to maximize the use of village's own supplies (combined in micro-grids supplied by renewable energy sources) and reduce the necessity of use of national network. According to data quoted by Hawasly, Corne, Roaf [2010] who investigated the optimizing of energy consumption in the experimental Riccarton Ecovillage (Scotland) consisting of 20 homes, savings in energy consumption can achieve the value 35-40\% [12].The Global Ecovillage Network (GEN), established in 1996, defines eco-villages as: "an intentional or traditional community using local participatory processes to holistically integrate ecological, economic, social, and cultural dimensions of sustainability in order to regenerate social and natural environments"[13].UN-Habitat, the agency responsible for promoting sustainable communities, has included eco-villages in its database of the top 100 listing of Best Practices since 1998.

\subsection{Cloughjordan Eco-village, Ireland}

The development began in 2007 in a rural area of the midlands region in Ireland, approximately 1.5 hours from the capital city of Dublin. The eco-village is accessible by train from various urban centres. In 2002 Sustainable Projects Ireland Ltd (SPIL) a nonprofit organization, identified a site for location of the new Eco-village, to minimize the cost of investment - adjacent to existing town-Cloughjordan. The Village Ecological Charter stipulates the energy requirements for new dwellings (30 percent below the input allowed by the 2006 Building Regulations) and establishes total energy usage for single family house of $84 \mathrm{kWh} / \mathrm{m}^{2} \cdot \mathrm{yr}$ [14]. To achieve this goals the technologies of high level of insulation had to be incorporated in the building's construction. An Cloughjordan Eco-village heating system is based on wood chips and a solar panel field. The eco-village is connected to a sustainable drainage system ( $\mathrm{SuDS}$ ). The entire village, located on the area of 67 acre, when completed, will include mixed used environment, economic and socially friendly sustainable developments. According to the Master Plan, the Cloughjordan Eco-village will incorporate 130 energy efficient residential dwellings, green and educational centre, eco-hostel, allotments and community gardens and leisure facilities. 
Located along the village stream the pedestrian greenway will join two green centres with playgrounds [14].

\section{Eco-district}

Eco-districts are characterized by positive environmental impacts and increase wellbeing of local communities. EcoDistricts ${ }^{\mathrm{TM}}$, a nonprofit organization in the US, defines them as "a whole systems green neighborhood investment strategy that integrates resource efficiency, ecological diversity, mobility, and community wellbeing" [15]. In eco-districts energy costs are reduced by constructing buildings with low energy consumption in sense of: materials, orientation, insulation and ventilation. The eco-district consists of positive energy buildings, which produce more energy than they consume. Technologies and strategies of sustainability development incorporate: renewable energy, water and zerowaste management, green streets, smart green, rainwater harvesting, greenways (pedestrian paths and bike lanes), TOD (Transport Oriented Development), multimodal transit, urban Eco-farms and new green areas planning. Strong community vitality and active and diverse participation are distinguished features of an eco-district's society. The EcoDistricts ${ }^{\mathrm{TM}}$ Framework [15] identifies eight goals of the eco-district such as: Equitable Development (understood as ensuring "fair distribution" of community benefits: job and investment opportunities), Health and Wellbeing (access to recreation and natural areas, healthy food, improving air quality), Community Identity, Access and Mobility (mix-uses, accessible services, promoting active transportation), Energy (efficient dispersed energy system based on renewable energy resources - solar, wind, biomass, geothermal), Water (reuse and recycle water resources, water stormwater management and water discharge system), Habitat and Ecosystem Function (increase biodiversity, connectivity within and beyond the system - ex. through green infrastructure, enhance watersheds) and Materials Management (reduce of waste, use of recycled materials, organic waste compositing).

Eco-districts are created as an alternative for urban sprawl with the principles of reducing energy costs and low energy consumption, through smart uses of building materials, smart orientation of residential blocks and natural ventilation and insulation incorporated in the architecture. Fitzgerald and Lenhart describe eco-districts as "a missing link between building scale and city or regional scale planning and implementation." [16]. Over the last two decades model eco-districts have been born in EU, with significant examples of: Vauban in Freiburg, Western Harbour in Malmö, Hammerby Sjöstad in Stockholm. Freiburg was awarded the Academy of Urbanism's European City of the Year Award in 2010, Malmö gained, among many others awards: a 2010 United Nations World Habitat Award for the revitalization of Augustenborg and in 2012 Malmö was a finalist for the European Green Capital designation [16]. Three of the most significant Northern European eco-districts (mentioned above), were built on post-industrial wasteland.

\subsection{Riesfield and Vauban Eco-districts, Freiburg. Transport innovative solutions}

Construction of Vauban (south-west Germany), established on the former military area, comprising 2,000 energy sustainable houses began in 1998, Riesfield in 1992. The 70 ha brownfield redevelopment investment was completed in 2010. Both habitats were designed as mix-use eco-suburbs with 3-5 story buildings, high density (in Vauban 122 persons/ha) pedestrian and bicycle friendly transport, new tram line and parking ratio less than 0.5 per 
house unit [17]. Car usage was limited to minimum through reduce of parking space and marking out parking-free residential streets and car-free zones. Most of the parking spaces are located in garages on the edge of the residential area. Construction of new buildings corresponds to high standards of thermal insulation, as the heating system is based on solar energy and woodchips. The innovative transport solutions include: increase of frequencies of local train, extension of city's tram system, a new transport interchange with 1000-space bike parking, "bike and ride" parking, u-shape, $4 \mathrm{~m}$ in width play streets, used as common community space, giving priority to pedestrians. Most of the district is marked a car-free residential area with access to tram stops within a 400- maximum distance from every single household [17].

\subsection{Bo01 Eco-district, Malmö, Sweden. Innovation in ecology}

Bo01 was launched on a 160 ha former industrial estate and port area with a principle of creating of sustainable, energy self-sufficient model residential unit for over 30,000 inhabitants. Bo01 is a high density urban unit, supplied by $100 \%$ renewable energy (sun and wind). Most of the heat for the district is delivered by community heat pump installation from natural underground reservoir. Bo01 Eco-district is equipped with 10 cold and warm wells in an aquifer with temperature of $10-11^{\circ} \mathrm{C}$ located in the ground at a depth of 40-70 meters[16]. The heat production is supported by $1400 \mathrm{~m}^{2}$ of solar collectors, connected to residential area heating system. The district comprehensive heating system produces 5,800 MWh of heath, 5,000 MWh cooling and 6,300 MWh electricity, which means it supplies $85,000 \mathrm{~m}^{2}$ of living space. $2 \mathrm{MW}$ wind turbine, placed in the northern part of the harbor and $120 \mathrm{~m}^{2}$ photovoltaic solar panels on the buildings supply the Bo01 Ecodistrict in electricity $[16,18]$. Rainwater drainage system, treated as a public space, includes waterfalls, gutters, artificial ponds for storage and to purify rainwater. The district topography has been changed to design natural rundown to the sea or to the canal, green roofs were used to reduce the amount of rainwater. Apart from about mentioned ecological technologies, the recycled water, raw materials and waste are reused. The area is characterized by relatively high biodiversity, diverse green areas, public spaces and green roofs [15].

\section{Sustainable city principles}

The search for the answer about the urban form, which the best suits the principles of sustainable city, has led to two dominant and contradictory theories: the compact and the dispersed city. The compact city theory is connected with a form of high density, mixed urban environment (housing, workplaces, services) based on semi-detached and multifamily housing. The compact city idea enables to reduce energy costs inside urbanized areas through low energy use, centralized heating system and reducing the demands for everyday travelling. The negative aspects of compact city and the belief that it: "rejects suburban and semi-rural living, neglects rural communities, affords less green and open space, increases congestion and segregation, reduces environmental quality and lessens the power for making local decisions" have contributed to the development of urban planning concepts which combine attitudes of compact city with dispersed city, such as: urban village, new urbanism, TOD transit-oriented development and smart growth $[19,20]$. 
The development of energy storage network opens the opportunities for local societies to undertake community initiatives, such as decentralized energy supply production. In some countries power providers are obliged to incorporate decentralized energy supply in the comprehensive energy production and distribution system. According to nowadays market requirements, energy production is partially based on municipality governed facilities and individual combined heat and power installations, what creates favourable conditions for the development of social network related to energy [21].

According Eco2 Cities, an initiative launched by the World Bank, as part of the World Bank Urban and Local Government Strategy,: "Ecological cities enhance the well-being of citizens and society through integrated urban planning and management that fully harnesses the benefit of ecological systems, and protects and nurtures these assets for future generations." [22]. To fulfill the requirements of minimal ecological footprint contemporary eco-city ought to be designed with principles of: 1) creating of compact, green and safe mix-used community 2) public transport priority with emphasis of "access to proximity" 3) revitalization of degraded land - postindustrial of other uses 4) supporting local production and agriculture, urban greening, community allotments and gardening 5) creating convenient, safe and economically mix housing 6) creating opportunities for the underprivileged people 7) recycling and resource conservation 8) supporting ecological activities 9) promotion of simple lifestyle 10) ecological education [23].

\subsection{Masdar Zero Carbon City}

Masdar, covering an area of seven square kilometres, was designed by architects Foster and Partners, as entirely carbon neutral, powered by renewable energy and supplied with electric transportation system settlement for about 40, 000 inhabitants. The Eco-city incorporates five separate units: Masdar City, Masdar Carbon, Masdar Capital, Masdar Power, and Masdar Institute of Science and Technology [24]. The Masdar investment was launched in 2006 with the aim to create low-energy environment, habitat equipped with the newest renewable energy and sustainable technologies and as the demonstration project of the practical usage of renewable energy technologies on a utility scale $[25,26]$. The urban grid layout is based on narrow streets shaded by buildings, to reduce the need for air conditioning, covered with solar panels. Among technical solutions to achieve sustainability goals within the city are: electrically powered public transport system, intelligent monitoring system applied in buildings and utility supplied system, recycling of waste and water, composing of biodegradable materials, energy system based on photovoltaic plants, a solar thermal power plant, evacuated thermal tube collectors, a wasteto-energy plant and a solar cooling system [26]. The photovoltaic panels (PV) on the roofs, constructed as first parts of the structures enable to generate energy needed to construct the rest of the building. Masdar is connected to Abu Dhabi national power grid to balance the electricity demands (overproduction during the day and shortfall during the night) [26]. These technical innovations are supplemented by architecture design, such as: location of air wells above courtyards, shading the streets and facades of buildings. The government of Abu Dhabi announced that Masdar would aim "to be zero-carbon, powered entirely by renewable energy, car-free, and produce net-zero waste". The sustainability principles include: reduce of energy demand and embodied and operational carbon produced by the city, water by $30 \%$ and landfill waste by $50 \%$ [24]. 


\subsection{Dongtan Zero Carbon City}

Dongtan City on Chongming Island - the world's largest alluvial island is situated about nine miles from Shanghai's financial district. It is estimated, that Dongtan will house 25,000 residents by the 2010 and half of million inhabitants by 2050 [24, 27]. Dongtan is adjacent to the Chongming Dongtan National Nature Reserve registered on the List of Wetlands of International Importance (the Ramsar List). The Eco-city will consist of a city center (formed of three villages) and pedestrian-friendly small mix-use towns, including residential, working and services infrastructure, connected by bicycle routes and public transport. Dongtan is seen as the demonstration project which outlines direction for future development of new Eco-cities in China - Langfang, Wuxi, Tangshan, and Tianjin [27]. According to the Dongtan Master Plan and estimated measures of the impact of the investment on the environment: the Eco-city will have $60 \%$ smaller ecological footprint in comparison with other Chinese cities, energy demand will be reduced by $66 \%$, waste to landfills by $83 \%, 40 \%$ of energy will come from bio-energy and no CO2 emissions [27, 28]. Moreover: "This project is expected to become a showcase for technologies and urban design that help to protect the environment while maintaining economic growth and social development. Dongtan eco-city was designed following an "integrated urbanism" approach that considers the environment, social, and economic aspects to create sustainable communities." [27]. Shanghai Institute of Urban Planning and Design for Chongming, Dongtan [2001] established functional zones planned at Dongtan : residential zone, artificial lake, wetland park, bird protection and education zone, education and research park, research and development park, land recreation area, water recreation area, transit centre, organic farm and experimental zone, eco-industry zone, aquatic farm and hatchery, landscaping and urban forestry, modern agriculture area, reserved land and others [27].

Design principles combine:

1. location and building design (compact, medium density residential area consisting of four to eight story buildings built using local and recycled materials),

2. energy system (energy self-sufficient city based on renewable sources: solar, wind, and biomass, using passive design: natural ventilation, natural insulation, green roofs, on-site energy system with photovoltaic cells and micro wind turbines applied in buildings, out-site energy system with wind turbines plant, waste to energy system, combined heat and power plant located on the edge of the city),

3. water management system (comprehensive system of potable water management and reclaimed water management for irrigation and toilets, rainwater storage system, sewage biological treatment system, flood control system)

4. waste management system (recycling of solid waste, composing of organic and human waste used as biogas to generate energy and fertilizer for farming)

5. transport system ("park and way" system, prioritize of public transport with public transport stops within distance of 500 meters from every single house, tram, bus, bicycle, and pedestrian networks, exclusion of Gas and diesel vehicles from the city, hydrogen power stations located in various points in the city)

6. food delivery and production system (local organic farming combined with waste and sewage recycling systems, usage of hydroponic techniques) ecosystem (3.5 $\mathrm{km}$ buffer zone between the city and wetlands, $60 \%$ of the Dogtan Eco-city reserved for to farms, parks, and wetlands, principle of 27 square meters of green areas per-capita, greening the city program - increasing the biodiversity along planned canals, streams, streets and green roofs) 
7. social and economic development strategy (eco-industry, tourism, safe and diversified community goals) $[27,28]$

\section{Conclusion}

Sustainable residential areas are urban units designed with consideration of minimal environmental impact, they cause the smallest possible ecological footprint through efficient use of energy, water and food resources and require minimal amount of waste and pollution. To achieve these principles, a sustainable residential area is basing on local materials and energy, using geographic location to incorporate sunlight, wind and rain into urban technologies and takes advantages of natural ecosystems and vegetation to improve urban microclimates and reduce pollution. Savings in energy consumption are used to enhance the role of urban public spaces and public transport and as results which enables to create new vibrant communities and improve welfare of inhabitants. Medium density sustainable urban settlements offer the best adapted energy self-sufficient solutions incorporated in architecture design. It is estimated, that by $2050,70 \%$ of the world's population will live in cities and cities will accommodate more than 2.5 billion of additional residents. Nowadays, urban settlements are responsible for one-third of energy use worldwide, and over $20 \%$ of man-made $\mathrm{CO} 2$ emissions. Buildings, using less energy to heat, cool, ventilate, lighting are technically and financially possible. Existing technologies represent spectrum of possibilities for cities to operate at low levels of energy consumption, using renewable energy sources, local materials, air and water flows and incorporating natural ecosystems into urban areas

\section{References}

1. National Science \& Technology Council, Federal Research and Development Agenda for Net-Zero Energy, High Performance Green Buildings, Committee on Technology, , finalreport.http://www.bfrl.nist.gov/buildingtechnology/documents/FederalRDAgendaf orNetZeroEnergyHighPerformanceGreenBuildings.pdf (2008)

2. V. Novotny, Water/Energy Interactions of Water Reuse, 37-57 (2012)

3. V. Novotny, Water Sci. Technol. 63, 1, 184-90 (2011)

4. Communication From the Commission to the European Parliament, COM (2011), 112 final (2011)

5. D. D'Agostino, J. of Build. Eng. 1, 20-32 (2015)

6. J. Laustsen, Energy Efficiency Requirements in Building Codes, Energy Efficiency Policies for New Buildings (2008)

7. Directive 2010/31/EU Off. J. Eur. Union, 13-35 (2010)

8. A. Kylili, P.A. Fokaides, Sustain. Cities and Soc. 15, 86-95 (2015)

9. H. Lund, A. Marszal, P. Heiselbergb, Energ.Build. 43, 7, 1646-1654 (2011)

10. R. Gilman, In Context 1 (1991)

11. J. Dawnson, Ecovillages. New Frontiers for Sustainability (2006)

12. M. Havasly, D. Corne, S. Roaf, Arch. Sc. Rev. 53, 1, 126-140 (2010)

13. Global Ecovillage Network What is an Ecovillage? Retrieved from http://gen.ecovillage.org (accessed 15.03.2017) (2011) 
14. N. Winston, Adv.in Ecopolitics 9, 85-103 (2012)

15. Ecodistrict Institute, retrieved from https://ecodistricts.org/wpcontent/uploads/2013/07/resourceguide_web2.pdf (accessed 15.03.2017) (2012)

16. J. Fitzgerald, J. Lenhart, Env. and Plan. C: Government and Policy 34, 2, 1-17 (2015)

17. S. Field, Low Car(Bon) Communities. Inspiring car-free and car-lite urban futures, 23-39 (2016)

18. G. Austin, Journ. of Green Build. 8, 34-50 (2009)

19. E. Holden, I.T. Norland, Urban Studies 42, 12, 2145-2166 (2005)

20. H. Frey, Designing the City: Towards a More Sustainable Urban Form (1999)

21. T. Schoor, B. Scholtens, Renew. and Sust. Ener. Rev. 43, 666-675 (2015)

22. H. Suzuki et al. Eco2 Cities Ecological and Economic Cities (2010)

23. M. Roseland, Cities 14, 197-202 (1997)

24. A.Alusi, R.G.Eccles, A.C.Edmondson, T.Zuzul, Sustainable Cities: Oxymoron or the Shape of the Future? HBS Working Paper 11-062, (2011)

25. S. Nader, Energ. Procedia 1, 3951-3958 (2009)

26. D. Reiche, Energ. Policy 38, 378-382 (2010)

27. H. Cheng, J.Hu, J. Environ. Monit. 12, 119-126 (2010)

28. I. Chang, E. Sheppard, Journ. of Urb. Tech. 20, 1, 57-75 (2013) 